\title{
PODSTAWY PRAWNE, DETERMINANTY I PRAKTYCZNE PRZYKŁADY WSPÓŁPRACY TRANSGRANICZNEJ
}

\section{LEGAL BASES, DETERMINANTS AND PRACTICAL EXAMPLES OF CROSS-BORDER COOPERATION}

\author{
Mieczysław Adamowicz ${ }^{1(\mathrm{~A}, \mathrm{C}, \mathrm{D}, \mathrm{E}, \mathrm{F}, \mathrm{G})}$, Paweł Janulewicz ${ }^{2(\mathrm{~A}, \mathrm{~B}, \mathrm{C}, \mathrm{D}, \mathrm{E}, \mathrm{F})}$ \\ ${ }^{1}$ Państwowa Szkoła Wyższa im. Papieża Jan Pawła II w Białej Podlaskiej \\ ${ }^{2}$ Uniwersytet Przyrodniczy w Lublinie
}

\begin{abstract}
Adamowicz, M., Janulewicz, P. (2018). Podstawy prawne, determinanty i praktyczne przykłady współpracy transgranicznej. Rozprawy Społeczne, 12(2), 57-64. https://doi.org/10.29316/rs.2018.20

Wkład autorów:

A. Zaplanowanie badań

B. Zebranie danych

C. Dane - analiza i statystyki

D. Interpretacja danych

E. Przygotowanie artykułu

F. Wyszukiwanie i analiza

literatury

G. Zebranie funduszy
\end{abstract}

Tabele: 0

Ryciny: 0

Literatura: 22

Otrzymano: maj 2017

Zaakceptowano: wrzesień 2017

\section{Wstęp}

Zmiany ustrojowe zapoczątkowane w Polsce w latach 90., a także późniejsze zmiany sytuacji geopolitycznej szczególnie w Europie Środkowo-Wschodniej doprowadziły do aktywizowania samorządów do współpracy transgranicznej. Warto jednocześnie podkreślić, że zasadnicze zmiany następowały również na poziomie państwa, co znajdowało swoje odzwierciedlenie w przyjętych priorytetach polskiej polityki zagranicznej, wśród których podkreślano znaczenie m.in. współpracy transgranicznej i regionalnej jako czynnika podnoszącego konkurencyjność zarówno Polski jak i UE. Obecnie, transgraniczna współpraca zarówno polskich jak i zagranicznych regionów znajduje się w fazie ciągłego rozwoju. Jest ona uznawana jako efektywne narzędzie wspierające rozwój zaangażowanych jednostek mające swoje odzwierciedlenie w szeregu inicjatyw i programów europejskich (Zabielska, 2013, s. 46). Głównym ce- lem opracowania jest wskazanie ram prawnych form i praktycznych efektów współpracy transgranicznej wybranych regionów Polski i UE.

\section{Podstawy prawne współpracy transgranicznej}

Najważniejszym aktem prawnym w Polsce jest Konstytucja Rzeczpospolitej Polskiej, która $\mathrm{w}$ art. 172 wskazuje, że jednostki samorzą$\mathrm{du}$ terytorialnego maja prawo do zrzeszania się oraz przystępowania i współpracy $\mathrm{z}$ międzynarodowymi społecznościami lokalnymi i regionalnymi przy czym zasady tej współpracy na forum międzynarodowym określają odrębne ustawy (Dz.U. 1997 nr 78 poz. 483). Jedną z nich jest Ustawa z dnia 15 września 2000 r. o zasadach przystępowania jednostek samorząu terytorialnego do międzynarodowych zrzeszeń społeczności lokalnych i regionalnych, które w bardzo szczegółowy sposób określa reguły jakie mają być spełnione

Adres korespondencyjny: Mieczysław Adamowicz, Państwowa Szkoła Wyższa im. Papieża Jana Pawła II w Białej Podlaskiej, ul. Sidorska 95/97, 21-500 Biała Podlaska, e-mail: adamowicz.mieczyslaw@gmail.com, tel.: 833449900

Copyright by: Państwowa Szkoła Wyższa im. Papieża Jana Pawła II w Białej Podlaskiej, Mieczysław Adamowicz, Paweł Janulewicz

Czasopismo Open Access, wszystkie artykuły udostępniane są na mocy licencji Creative Commons Uznanie autorstwa-użycie niekomercyjne-na tych samych warunkach 4.0 Międzynarodowe (CC BY-NC-SA 4.0, http://creativecommons.org/licenses/by-nc-sa/4.0/). 
podczas podejmowania współpracy międzynarodowej. W Art. 2. 1. określono, że „jednostki samorządu terytorialnego mogą przystępować do zrzeszeń i uczestniczyć w nich w granicach swoich zadań i kompetencji, działając zgodnie z polskim prawem wewnętrznym, polityką zagraniczną państwa i jego międzynarodowymi zobowiązaniami" (Dz.U. 2000 nr 91 poz. 1009, s. 1). Art. 4. 1. określa, że tylko organ stanowiący JST może podjąć decyzję (w formie uchwały) o przystąpieniu do międzynarodowych organizacji. W Art. 10.1. zwrócono uwagę, że w momencie zmiany celów lub zasad zrzeszenia do którego przystąpiły JST wszystkie decyzje w sprawie dalszej współpracy muszą być podejmowane przez organ stanowiący jednostki w formie uchwały. Warto jednocześnie zwrócić uwagę, że „w przypadku pojawienia się rozbieżności pomiędzy celami polityki zagranicznej państwa a polityką zrzeszenia minister właściwy do spraw zagranicznych może cofnąć zgodę na przystąpienie do zrzeszenia" (Dz.U. 2000 nr 91 poz. 1009, s. 1-4). W Art. 14. 1. przedstawiono zasady jakie obowiązują JST, które przystąpiły do zrzeszeń przed wejściem omawianej ustawy (Dz. U. $2000 \mathrm{nr} 91$ poz. 1009, s. 1-4).

Jak już wspomniano JST mogą wchodzić w skład zrzeszeń tylko w zakresie posiadanych przez siebie kompetencji zgodnych z założonymi celami polityki zagranicznej państwa określonymi jako: priorytety polskiej polityki zagranicznej określonej na lata 2012-2016. Warto podkreślić, że niniejszy dokument jest nadal ważnym wskazaniem dla władz samorządowych koordynującym współpracę zagraniczną (Priorytety polskiej polityki zagranicznej 2012-2016).

Kolejnym ważnym dokumentem opisującym zasady współpracy międzynarodowej pomiędzy JST jest Europejska Karta Samorządu Terytorialnego, sporządzona w Strasburgu dnia 15 października 1985 r. a ratyfikowana w całości w Polsce w 1994 roku. W art. 10 „Prawo społeczności lokalnych do zrzeszania się" zwrócono uwagę, że społeczności lokalne mają prawo zrzeszać się z innymi społecznościami $\mathrm{w}$ celu realizacji wspólnych zadań przy czym podkreśla się, że wszystkie aktywności muszą być zgodne z lokalnym prawem. W EKST zwrócono również uwagę na to, że „prawo do przystąpienia do międzynarodowego stowarzyszenia społeczności lokalnych będzie uznane w każdym państwie"(Dz. U. 1994 nr 124 poz. 607, s. 2202).

Analizując akty prawne dotyczące współpracy transgranicznej, stanowiące swoiste ramy dla współpracy międzynarodowej nie sposób pominać konwencji i umów międzynarodowych dotyczących współpracy w ramach Euroregionów. Oprócz już wcześniej wymienionej Europejskiej Karty Samorządu Terytorialnego warto również zwrócić uwagę na (pobrane z http://www.euroregion-beskidy. $\mathrm{pl} / \mathrm{pl} /$ index.php?option=com_content\&view=article\&id=62\&Itemid=60):

1. Europejską Kartę Regionów Granicznych i Transgranicznych z 20 listopada 1981 r., która zawiera syntezę doświadczeń europejskich, określa cele i metody wykorzystywane do rozwiązywania problemów występujących na obszarach przygranicznych. Jest dokumentem Stowarzyszenia Europejskich Regionów Granicznych, w którym podkreślono rolę wzajemnego zaufania w sąsiedzkich stosunkach międzynarodowych.

2. Europejską Konwencję Ramową o współpracy transgranicznej między wspólnotami i władzami terytorialnymi tzw. Konwencję Madrycką z dnia 21 maja 1980 r., do której Polska przystąpiła w 1993 roku. Dokument podkreśla znaczenie współpracy przygranicznej mającej na celu kształtowanie poczucia wspólnoty łączącej regiony i narody.

3. Europejską Kartę Samorządu Regionalnego z dnia 5 czerwca 1997 roku sporządzoną przez Kongres Władz Lokalnych i Regionalnych mającą na celu tworzenie europejskich standardów ułatwiających współpracę międzynarodową.

4. Traktat o Unii Europejskiej - stanowiący swoiste ramy współpracy międzynarodowej.

Współpracę transgraniczną wspierają następujące instytucje: Kongres Władz Lokalnych i Regionalnych (CLARE), Komitet Zarządzający Władz Lokalnych i Regionalnych (CEMR), Komitet Regionów przy Unii Europejskiej oraz Stowarzyszenie Europejskich Regionów Granicznych (SERG). Do głównych zadań SERG należy: „definiowanie problemów, określanie szans, obowiązków i programu działań europejskich regionów granicznych i transgranicznych, reprezentowanie ich wspólnych interesów wobec narodowych i ponadnarodowych parlamentów, ciał, władz i instytucji, inicjowanie, wzmacnianie i koordynowanie współpracy pomiędzy europejskimi regionami granicznymi i transgranicznymi, wymianę doświadczeń i informacji w celu wyodrębnienia wspólnych interesów, koordynowanie ich realizacją oraz rozwiązywanie rozmaitych problemów z jakimi borykają się Euroregiony" (pobrane z: http://www.euroregion beskidy. $\mathrm{pl} / \mathrm{pl} /$ index.php?option=com_content\&view=article\&id=62\&Itemid=60).

Kolejną ważną inicjatywą w drodze do budowania relacji międzyregionalnych była europejska polityka sąsiedztwa (EPS), która opiera się na następujących aktach prawnych:

1. Traktat o Unii Europejskiej: Art. 8 mówiący, że „Unia rozwija szczególne stosunki z państwami z nią sąsiadującymi, dążąc do utworzenia przestrzeni dobrobytu i dobrego sąsiedztwa, opartej na wartościach Unii i charakteryzującej się bliskimi i pokojowymi stosunkami opartymi na współpracy", a do tego celu może zawierać specjalne umowy (Traktat o Unii Europejskiej),

2. Traktat o funkcjonowaniu Unii Europejskiej Art. 206-207 odnoszący się do wspólnej polityki handlowej opisujące jej zasady i procedury. W Art. od 216 do 219 zostały szczegółowo opisane zasady i warunki zawierania umów międzynarodowych (Traktat o funkcjonowaniu UE). 


\section{Determinanty i formy współpracy międzyregio- nalnej}

Jak podkreśla Zabielska współpraca ekonomiczna między regionami może występować $\mathrm{w}$ formie: wzajemnego poznawania się i wymiany informacji; wspólnej analizy przez zainteresowane strony różnych zagadnień problemowych (poprzez aktywność mieszanych grup roboczych); wypracowywania wspólnych stanowisk w negocjacjach i przedstawiania opinii o możliwych rozwiązaniach problemów; realizacji wspólnych projektów oraz instytucjonalizacji wspólnego wykonywania zadań w zakresie współdziałania na rzecz rozwoju (Zabielska, 2013, s. 47-48).

Bardzo szeroko obszary współpracy transgranicznej zostały opisane w Europejskiej Karcie Regionów Granicznych i Transgranicznych. Zwrócono szczególną uwagę na skutki istnienia granic, które nazywano „bliznami historii”. Jako główne cele współpracy transgranicznej wskazano (Europejska Karta Regionów granicznych i transgranicznych, s.9-12):

1. Tworzenie nowej jakości granic - niwelowanie granicy jako bariery prowadzące do lepszej współpracy pomiędzy mieszkańcami terenów nadgranicznych, a tym samym urzeczywistnienia idei „Europy obywateli”. Warto przy tym zauważyć, że z punktu widzenia administracyjnego jak i suwerenności kraju granice nadal będą funkcjonować, natomiast $\mathrm{z}$ punktu widzenia życia mieszkańców terenów przygranicznych celem jest niwelowanie granic mające na celu integrowanie społeczności prowadzące do poszukiwania wspólnych sposobów wdrażania lepszej współpracy we wszystkich dziedzinach życia.

2. Umacnianie warunków gospodarczych i społeczno-kulturowych ma na celu głównie stwarzanie dogodnych warunków współpracy gospodarczej i infrastrukturalnej ale również znoszenie barier zarówno socjalnych jak i oświatowych (wsparcie nauki języków obcych) oraz kulturowych.

3. Kreowanie partnerstwa i subsydiarności - budowa współpracy międzyregionalnej musi jednocześnie zachowywać odrębności i struktury wyrosłe na gruncie regionalnym wspierać ich zachowanie i rozwój. Nie należy jednocześnie wykluczać regionów, które są w sposób szczególny „upośledzone” tylko nadal z nimi się solidaryzować. Ważne jest, aby systematycznie doskonalić współpracę transgraniczną, która może przebiegać na różnych szczeblach od szczebla państwowego (komisje rządowe) aż do szczebla gminnego (przedsiębiorstwa komunalne).

4. Łączenie sąsiadów - regiony graniczne i transgraniczne wzdłuż granic UE pełnią funkcję pomostów prowadzących do rozwoju dzięki swojej bliskości do obywateli.

5. Ujednolicenie zagospodarowania przestrzennego $\mathrm{w}$ Europie - celem jest zapewnienie porównywalnej jakości życia mieszkańców.
Uwzględnianie warunków naturalnych, potrzeb infrastrukturalnych, gospodarczych i społecznych nie zapominając o ochronie środowiska. Stworzenie wspólnych ram prawnych współpracy w tym obszarze zawartych w Europejskiej Karcie Zagospodarowania Przestrzennego „Europa 2000+" oraz Europejskiej Koncepcji Rozwoju Przestrzennego.

6. Niwelowanie dysproporcji i przeszkód gospodarczych oraz infrastrukturalnych - poprzez usuwanie przeszkód i braków w transgranicznym przepływie osób i rzeczy. Należy usuwać niedobory wyposażenia infrastrukturalnego stref nadgranicznych oraz łagodzić dysproporcje w dochodach występujące na zewnętrznych granicach UE oraz w Europie Środkowo-Wschodniej.

R. Szul (2001) podkreśla, że współpraca transgraniczna zależy od wielu czynników, które zalicza do pięciu podstawowych grup (Zabielska, 2013, s. 52-53):

1. ekonomicznych, ze szczególnym uwzględnieniem poziomu rozwoju obu części obszaru transgranicznego, spójności systemów ekonomicznych oraz aktualnej koniunktury głównie w dziedzinie cen, płac, kursów walut i bezrobocia;

2. geograficznych, głównie sieci osadniczej na terenach przygranicznych, warunków naturalnych (ukształtowanie terenu i cechy środowiska przyrodniczego), a także infrastruktury granicznej

3. instytucjonalnych, dotyczących m.in. statusu granicy, a przede wszystkim regulacji wizowych, paszportowych i celnych oraz kompetencji władz regionalnych i lokalnych po obu stronach granicy;

4. polityczno-międzynarodowych, polegających na wpływie ogólnej atmosfery politycznej na wzajemne kontakty, uwzględniając relacje pomiędzy ogólną a lokalną sytuacją polityczną;

5. socjokulturowych i językowych, składających się m.in. z negatywnych stereotypów i uprzedzeń, a także barier językowych.

6. Europejska polityka sąsiedztwa (EPS) została sformułowana w 2004 roku w celu poprawy powszechnego dobrobytu, ograniczenia podziałów pomiędzy rozszerzoną UE a jej sąsiadami, poprawy stabilności i bezpieczeństwa. EPS jest głównie polityką dwustronną między 16 najbliższymi sąsiadami UE (Algierią, Armenią, Azerbejdżanem, Białorusią, Egiptem, Gruzją, Izraelem, Jordanią, Libanem, Libią, Marokiem, Mołdawią, Palestyną, Syrią, Tunezją oraz Ukrainą) a UE (pobrane z: http://www.europarl.europa.eu/atyourservice/ $\mathrm{pl} /$ displayFtu. html?ftuId=FTU_6.5.4.html).

W Polsce mamy następujące Euroregiony przy granicy państwowej (pobrane z: http://wroclaw. stat.gov.pl/cps/rde /xbcr/wroc/ASSETS_14-19.pdf, s.14-19):

1. Zachodniej (Pomerania - założony 15.12.1995 r., Neisse-Nisa-Nysa założony 21.12.1995 r., Pro Eu- 
ropa Viadrina - założony 21.12.1993 r., SprewaNysa-Bóbr założony 21.09.1993 r.)

2. Południowej: (Glacensis - założony 5.12.1996 r., Pradziad - założony 2.07.1997 r., Tatry - założony 26.08.1994 r., Karpacki - założony 14.02.1993 r., Śląsk Cieszyński - założony 22.04.1998 r., Silesia - założony 20.09.1998 r., Beskidy - założony 9.06.2000 r.),

3. Wschodniej (Bug - założony 29.09.1995 r., Niemen - założony 6.06.1997 r., Puszcza Białowieska - założony 25.05.2002 r.),

4. Północnej (Bałtyk - założony 22.02.1998 r.).

Przy wschodniej granicy warto zwrócić szczególną uwagę na grupę państw sąsiadujących z Polską z punktu widzenia zaawansowania procesów współpracy transgranicznej składającej się z: Ukrainy, Białorusi, Litwy i Rosji (obwód kaliningradzki). Na granicy: (pobrane z: http://wroclaw.stat.gov.pl/ cps/rde /xbcr/wroc/ASSETS_14-19.pdf, s.19):

1. Ukrainy - funkcjonują 4 euroregiony: Karpacki (ukraińsko-polsko-słowacko-rumuńsko-węgierski), Bug (ukraińsko-polsko-białoruski), Upper Prut i Lower Danube (ukraińsko-mołdawsko-rumuński);

2. Białorusi - działają 4 euroregiony: Bug (ukraińsko-polsko-białoruski), Puszcza Białowieska (białorusko-polski), Niemen (białorusko-polsko-litewski) i Country of Lakes Ezeru Zeme (białorusko-łotewsko-litewski);

3. Litwy - funkcjonują 4 euroregiony: Bałtyk (litewsko-polsko-rosyjsko-duńsko-szwedzki), Niemen (białorusko-polsko-litewsko-rosyjski), Country of Lakes Ezeru Zeme (białorusko-łotewsko-litewski) i SAULE (łotewsko-litewsko-rosyjski);

4. Rosji - (obwód kaliningradzki) działają 4 euroregiony: Bałtyk (litewsko-polsko-rosyjsko-szwedzko-duński), SAULE (łotewsko-litewsko-rosyjski), Niemen (białorusko-polsko-litewsko-rosyjski) i Łyna-Ława (polsko-rosyjski).

\section{Przykłady wybranych programów współpracy transgranicznej}

\section{Współpraca transgraniczna między Polską i Czechami}

W ramach projektu współfinansowanego przez UE ze środków EFRR Programie Operacyjnym Współpracy Transgranicznej Republika Czeska Rzeczypospolita Polska 2007-2013 został powołany do życia projekt, który w 2014 roku zmienił nazwę z Europejskiego Ugrupowania Współpracy Terytorialnej w skrócie „EUWT” na „EUWT NOVUM z o.o.”. Dnia 17.07.2014 roku Sejmik Województwa Dolnośląskiego podjął decyzję o przystąpieniu do ww. ugrupowania (pobrane z: http://www.umwd. dolnyslask.pl/ewt/projekty-wlasne-urzedu/strategia-zintegrowanej-wspolpracy-czeskopolskiegopogranicza/aktualnosci/artykul/polsko-czeskie-euwt-zmienilo-nazwe-1/). Jak wynika z dokumentów założycielskich „Ugrupowanie zostało utworzone w celu intensyfikacji, ułatwiania i upowszechniania polsko-czeskiej współpracy transgranicznej na rzecz wzmocnienia spójności ekonomicznej i społecznej obszaru działania Ugrupowania". Utworzone Ugrupowanie miało charakter wielostronnego partnerstwa w skład, którego wchodziło 9 jednostek (Adamczuk F., 2015, s. 108-109): pięć z pogranicza polsko-czeskiego województwo dolnośląskie, Kraj Kralowohradecki, Kraj Ołomuniecki, Kraj Liberecki, Kraj Pardubicki, dwie jednostki z pogranicza polsko-niemiecko-czeskiego euroregionu Neisse-NisaNysa: strona polska reprezentowana przez Stowarzyszenie Gmin Polskich Euroregionu Nysa i strona czeska reprezentowana przez Regionálni komunálni sdruženi měst a obci severnich Čech oraz dwie jednostki z programu polsko-czeskiego euroregionu Glacensis: Stowarzyszenie Gmin Ziemi Kłodzkiej wraz z czeskim Regionalnym Stowarzyszeniem do spraw Współpracy Pogranicza Czech, Moraw i Ziemi Kłodzkiej. Istotą, a zarazem głównym celem było efektywniejsze wykorzystywanie funduszy unijnych mających charakter projektów transgranicznych. Posiadanie przez ugrupowanie osobowości prawnej ułatwiało samodzielne aplikowanie o środki z UE, mające na celu wspieranie rozwoju całego pogranicza. Głównym obszarem realizowanych przedsięwzięć była turystyka. Wykorzystując środki UE wspierano rozwój klastra turystycznego poprzez tworzenie wspólnej oferty turystycznej dla państw wchodzących w skład Ugrupowania. EUWT NOWUM sp. z o.o. za cele szczegółowe postawiła sobie: wspieranie i poprawę ochrony zasobów naturalnych i kulturowych, zapobieganie zagrożeniom naturalnym i technologicznym, poprawę dostępu do usług i sieci transportowych, informatycznych i komunikacyjnych oraz wspieranie przedsiębiorczości ze szczególnym uwzględnieniem małych i średnich przedsiębiorstw. Ugrupowanie wspiera rozwój klastra turystycznego na pograniczu polsko-czeskim nie stanowiąc jednocześnie podmiotu konkurencyjnego dla współpracy transgranicznej w odniesieniu do istniejących euroregionów i jak podkreśla Adamczuk „wnosi nową jakość do współpracy transgranicznej”, posiadając przy tym „ogromny potencjał rozwojowy” (Adamczuk, 2015, s.109-111).

\section{Współpraca transgraniczna Republiki Słowac- kiej i Austrii}

Procesy integracji europejskiej w tym regionie przechodziły swoistą transformację wraz z upływającym czasem, zmieniając się $\mathrm{z}$ barier (przed 1989 rokiem) na czynniki rozwoju. Za początek współpracy Słowacji z Austrią należy uznać podpisanie dwustronnych porozumień oraz ratyfikację przez Słowację europejskich konwencji współpracy transgranicznej, w skład której weszły: Europejska Karta Samorządu Lokalnego oraz Europejska Konwencja Ramowa o Współpracy Transgranicznej między Wspólnotami i Władzami Terytorialnymi (tzw. Konwencja Madrycka) (Mattoš, 2014, s. 189). 
Według Ivaničková i Vlčková (2005) podstawowym celem współpracy transgranicznej wspieranym przez UE jest integracja obszarów podzielonych granicami narodowymi, a mających wspólne problemy, które mogą być wspólnie rozwiązane (Mattoš, 2014, s. 189). Jak podkreśla Mattoš, rozdzielenie granicą państwową gospodarek, infrastruktury, ludności, systemów podatkowych było głównym powodem występowania ww. problemów i trudności rozwojowych, dlatego tak ważną rolę przybrały procesy integracyjne. Integracja prowadząca do włączania poszczególnych części terenów będzie efektywna jeżeli zostanie zaakceptowana przez mieszkającą tam społeczność. Charakter współpracy transgranicznej Słowacji i Austrii jest uwarunkowany długością linii granicznej. Po stronie słowackiej, obszar przygraniczny jest częścią stolicy Republiki Słowackiej - Bratysławy (jej dzielnic, leżących przy granicy z Austrią i Węgrami) oraz dwóch innych jednostek samorządu terytorialnego: kraju bratysławskiego i kraju trnawskiego. Po stronie austriackiej, obszar przygraniczny należy do krajów związkowych: Dolna Austria, Burgenland oraz Wiedeń" (Mattoš, 2014, s. 189-190).

Zdenek Št'astný (2013) podkreśla, że Bratysława pełni szczególną rolę w Republice Słowackiej ponieważ stwarza miejsca pracy dla $24,8 \%$ aktywnych zawodowo mieszkańców, a jednocześnie zamieszkuje ją tylko $8,4 \%$ populacji, warto przy tym zauważyć, że $w$ tym mieście jest bardzo rozwinięta przedsiębiorczość, najniższy poziom bezrobocia, a co za tym idzie najwyższe średnie zarobki. Wg wskaźnika PKB per capita (za 2014 rok) Bratysława jest na piątym miejscu w UE w rankingu najbogatszych regionów UE (Mattoš, 2014, s. 190). Według Dömötör (2013) podobną sytuację można zaobserwować po drugiej stronie granicy $\mathrm{w}$ Wiedniu. Około jedna czwarta PKB została wypracowana przez 20,4\% ludności zamieszkującej w Austrii. Wiedeń podobnie jak Bratysława ma bardzo rozbudowaną przedsiębiorczość skupiając ponad $26 \%$ austriackich przedsiębiorstw (Mattoš, 2014, s. 190). Podobieństwa obu miast spowodowały powstanie projektu pt. „Wiedeń-Bratysława - miasta bliźniacze". Inicjatywa ta składała się z kilku wspólnych projektów koncentrujących się głównie na rozwoju turystyki, rozwoju infrastruktury i transportu. Cechą charakterystyczną współpracy transgranicznej Wiedeń-Bratysława jest wyjątkowo bliska odległość dzieląca obie stolice. Obecnie $\mathrm{w}$ tym regionie rozwijany jest szerszy (czterostronny), regionalny program współpracy (Centrope), który jest swoistą kontynuacją programu Interreg IIIA zakończonego w 2007 roku. Nowy program ma za zadanie odzwierciedlić ideę nowego, szybszego rozwoju Europy Środkowo-Wschodniej opierającego się o cztery miasta: Brno (Republika Czeska), Wiedeń, Bratysławę i Győr (Węgry). Za priorytety programu uznano rozwój gospodarczy opierający się o rynek pracy, badania i naukę, infrastrukturę i transport, ochronę środowiska, kulturę i administrację publiczną (Mattoš, 2014, s. 191).

\section{Euroregion karpacki}

Euroregion karpacki został zawiązany dnia 14 lutego 1993 roku w Debreczenie. Skupia w sobie przygraniczne regiony z pięciu następujących państw: Polski, Słowacji, Rumunii, Ukrainy i Węgier. Prawnym jego reprezentantem jest Stowarzyszenie Euroregion Karpacki, który Polska powołała do życia w lipcu 2000 roku. Celem stowarzyszenia jest koordynowanie po polskiej stronie działań skupionych w nim członków, głównie samorządów (62) z woj. małopolskiego i podkarpackiego. Stowarzyszenie chce tworzyć dogodne warunki dla rozwoju przedsiębiorstw oraz kreowanie wyjątkowego miejsca do odpoczynku turystów z całego świata. Stowarzyszenie w swojej działalności wykorzystuje podejście partnerskie oraz projektowe opierające się na metodyce BPM (Bussines Project Management). Do głównych obszarów działalności Stowarzyszenia należy (Lechwar, 2012, s. 172-173):

- „współfinansowanie za pośrednictwem środków UE projektów transgranicznych,

- kompleksowa pomoc w wyszukiwaniu partnerów społecznych i gospodarczych na obszarze Karpat,

- pomoc w przygotowaniu projektów terytorialnych na obszarze Karpat,

- obsługa inwestorów, w szczególności kojarzenie partnerów gospodarczych,

- prowadzenie zespołów projektowych oraz przygotowywanie gotowych strategii i dokumentów planistycznych,

- pośrednictwo w kontaktach z władzami publicznymi oraz instytucjami około biznesowymi na obszarze Karpat,

- prowadzenie kampanii medialnych, promocyjnych i marketingowych".

Jednym $\mathrm{z}$ instrumentów wykorzystywanych do promocji walorów inwestycyjno - turystycznych województwa podkarpackiego jest program „Invest In Carpathians". Dwujęzyczna strona internetowa informująca o tym programie jest systematycznie aktualizowana. Można na niej znaleźć materiały dotyczące działalności Stowarzyszenia Euroregion Karpacki Polska, oraz zamieszczone oferty inwestycyjne, które są wzbogacone o zdjęcia i mapy oraz dane teleadresowe poszczególnych oferentów (Lechwar. Pobrane z: http://www.univ.rzeszow.pl/ file/ 21658/14. pdf, s.173). Jak podkreśla Lechwar do czynników sprzyjających rozwojowi współpracy transgranicznej Euroregionu Karpackiego należy zaliczyć: powiązania ekonomiczne, społeczne, gospodarcze jak również bliskość geograficzna. W ramach ww. Euroregionu można wyróżnić takie działania jak: ułatwienie dostępu do funduszy UE (samorządom i mieszkańcom), umożliwienie realizacji projektów ponad granicznych, prowadzenie działalności promocyjnej mającej na celu znalezienie zagranicznych partnerów dla przedsiębiorców zlokalizowanych na terenie Polski, organizowanie transgranicznych warsztatów, seminariów i wy- 
staw, wymiana osiągnięć naukowo-gospodarczych, tworzenie transgranicznych projektów dotyczących ochrony środowiska, planowania przestrzennego, infrastruktury technicznej oraz innych działań mających na celu poprawę komunikacji w ramach euroregionów dzięki tworzeniu wspólnych centów informacji europejskiej (Lechwar, 2012, s. 178).

\section{Współpraca międzynarodowa na przykładzie woj. warmińsko-mazurskiego}

W nowej strategii rozwoju społeczno - gospodarczego (do 2025 r.) woj. warmińsko - mazurskiego przyjętej w czerwcu 2013 r. zadeklarowano uczestnictwo w inicjatywach i instytucjach współpracy międzynarodowej w rejonie Morza Bałtyckiego w celu intensyfikacji stosunków gospodarczych. Głównym celem strategicznym w tym obszarze ma być doskonalenie administracji (wzrost liczby i jakości powiązań sieciowych). Podejmowana interwencja w obszarach przygranicznych ma na celu przezwyciężanie niedogodności związanych z położeniem geograficznym (wzdłuż granicy UE), a tym samym przeciwdziałanie ich marginalizacji. Jak podkreśla Modzelewski oczekiwanymi efektami ma być przede wszystkim: wykorzystanie szansy rozwoju małego ruchu przygranicznego prowadzącego do aktywizacji zarówno społecznej jak i gospodarczej (wzrost przedsiębiorczości); intensyfikacja współpracy międzynarodowej prowadzącej do poprawy powiązań komunikacyjnych w pasie przygranicznym oraz; podejmowanie wspólnych działań na rzecz tworzenia i promocji produktów turystycznych. Celem samorządów terytorialnych będzie również wspieranie przedsiębiorców w nawiązywaniu kontaktów z podmiotami zagranicznymi (Pobrane z: https://www. researchgate.net/publication/271588040_Kontakty_zagraniczne_samorzadu_wojewodztwa_warminsko-mazurskiego, s. 86).

\section{Współpraca transgraniczna polsko-niemiecka na przykładzie woj. lubuskiego i Branderburgii}

Zgodnie z polityką spójności na zachodniej granicy Polski powstał program z udziałem Polski i Brandenburgii mający na celu kreowanie sąsiedzkiej współpracy, prowadzącej do zbliżenia do siebie ludności po obu stronach granicy poprzez realizowanie wspólnych projektów. Prowadzone projekty mają przyczynić się do rozwoju pogranicza poprzez rozwój infrastruktury transgranicznej, tworzenie powiązań gospodarczych, poprawę stanu środowiska a także przełamywanie barier międzyludzkich. W latach 2007 - 2013 projektem zarządzała Polska, w nowej perspektywie 2014-2020 zarządzanie projektem przejęła strona niemiecka. Dotychczas, ze względu na cenne walory przyrodnicze pogranicza, w programie dominowały przedsięwzięcia, których celem było stworzenie atrakcyjnej oferty turystyczno-kulturalnej poprzez: zwiększenie dostępności komunikacyjnej (drogowej i rowerowej) i zrewitalizowanie miejsc i obiektów atrakcyjnych pod względem turystycznym np. obszary nadrzeczne na Nysie Łużyckiej w Euromieście Guben/Gubin i Odrze w Euromieście Słubice/Frankfurt nad Odrą, Dom Joannitów w Sulęcinie, Amfiteatr i Twierdza w Kostrzynie nad Odrą, Dom Bolfrasa we Frankfurcie itd. Oprócz rozwoju turystyki w ramach programu wspierano współpracę pomiędzy samorządami, przedsiębiorstwami, instytucjami otoczenia biznesu, a także uczelniami. W ramach projektu poprawiono również infrastrukturę społeczną np. wybudowano i wyposażono obiekty dla pożarowych służb ratunkowych (w Groß Gastrose i w Witnicy), zmodernizowano obiekty szkolne, rozbudowano trzy uczelnie wyższe, wybudowano i zmodernizowano dwa przedszkola (Słubice i Frankfurt nad Odrą), wybudowano i zmodernizowano wiele miejsc spotkań polsko-niemieckich (m.in. w Podlegórzu, Trebnitz, Szprotawie i Sprembergu) i wiele innych. Przygotowano także Program INTERREG VA na lata 2014-2020, który podobnie jak w latach poprzednich będzie realizował innowacyjne projekty mające na celu wspieranie rozwoju nadgranicznych obszarów (Pobrane z: https://www.ewt. gov.pl/media/858/PLBB_.pdf).

\section{Program Współpracy Transgranicznej Polska- -Białoruś-Ukraina 2014-2020}

Celem tego programu jest wspieranie procesów rozwojowych na pograniczu Polski, Białorusi i Ukrainy w szczególności (Pobrane z: http://www. pbu2020.eu/pl/pages/53):

1. „Promowanie rozwoju gospodarczego i społecznego w regionach po obu stronach wspólnej granicy;

2. Rozwiązywanie wspólnych wyzwań dotyczących środowiska, zdrowia publicznego, bezpieczeństwa i ochrony;

3. Promocja lepszych warunków i zasad zapewniających mobilność osób, towarów i kapitału".

Głównymi regionami, które skorzystają ze wsparcia w Polsce będa podregiony: krośnieński i przemyski (w województwie podkarpackim), białostocki, łomżyński i suwalski (w województwie podlaskim), bialski i chełmsko-zamojski (w województwie lubelskim), ostrołęcko-siedlecki (w województwie mazowieckim) oraz podregiony przyległe: rzeszowski i tarnobrzeski (w województwie podkarpackim); puławski i lubelski (w województwie lubelskim).

Na Białorusi wsparcie otrzymają: obwody główne (grodzieński i brzeski) oraz obwody przyległe (miński - łącznie z miastem Mińsk oraz homelski).

Po stronie Ukraińskiej udział w projekcie będa brały obwody główne (lwowski, wołyński, zakarpacki) oraz obwody przyległe (rówieński, tarnopolski, iwanofrankowski) (Pobrane z: http://www. pbu2020.eu/pl/pages/231).

Dnia 1 września 2016 został rozpoczęty proces przyjmowania wniosków tzw. dużych projektów 
infrastrukturalnych (DPI). Program Współpracy Trangranicznej Polska - Białoruś - Ukraina 20142020 obecnie zawiera 18 dużych projektów infrastrukturalnych wśród których 10 znajduje się na liście podstawowej a pozostałe na rezerwowej. Dotyczą one głównie poprawy i rozwoju usług transportowych i infrastruktury, podejmowania wspólnych wyzwań związanych $\mathrm{z}$ bezpieczeństwem, w tym wspierania efektywności i bezpieczeństwa granic oraz ochrony zdrowia jak również promocji lokalnej kultury i historii. Na ww. projekt przewidziano kwotę 52,07 mln Euro (Pobrane z: http:// www.pbu2020.eu/pl/pages/246).

\section{Wnioski}

Przemiany ustrojowe zapoczątkowane w Polsce w latach 90. oraz przystąpienie do Unii Europejskiej spowodowało, że Polska, ratyfikując akty prawne UE, może zgodnie z obowiązującym prawem korzystać z możliwości współpracy transgranicznej.

Jak wynika z przeprowadzonych analiz ta współpraca coraz bardziej się rozwija, a jest to skutkiem m.in. Programów Europejskich wspierających tę formę działalności. Głównym celem współpracy transgranicznej było (w poprzedniej perspektywie 2007-2013) i będzie w przyszłości (2014-2020) wspieranie rozwoju społeczno-gospodarczego jednostek współuczestniczących w projektach. Najczęściej odbywało się to za pomocą realizowania wspólnych działań mających na celu przybliżenie sobie przedsiębiorców z sąsiadujących krajów, wspieranie ich współpracy oraz promocja ich działalności. Wiele regionów chcąc osiągnąć założone cele skupiała się na posiadanych walorach krajobrazowo-przyrodniczych i w oparciu o nie tworzyła więzi współpracy międzyregionalnej mającej na celu m.in. zwiększenie dostępności komunikacyjnej (zarówno drogowej jak i rowerowej), rozwój przedsiębiorczości z branży turystycznej, wspieranie integracji społecznej poprzez współorganizowanie imprez kulturalno-oświatowych i wiele innych.

Mówiąc o współpracy międzyregionalnej nie sposób pominąć barier jakie pojawiają się przy realizacji projektów międzynarodowych, do których zaliczają się problemy społeczne związane m.in. „z niezabliźnionymi ranami historii”, które powodują nieufność wobec sąsiadów, a także dbałość o niezależność terytorialną. Dlatego tak ważne jest, aby podczas realizacji międzynarodowych projektów władze samorządowe podkreślały wspólne korzyści jakie można osiągnąć współpracując z regionami zagranicznymi zachowując przy tym swoją suwerenność.

\section{Literatura:}

1. Adamczuk, F. (2015). Uwarunkowania powstania Europejskiego Ugrupowania Współpracy Terytorialnej NOVUM (EUWT NOVUM) na pograniczu polsko-czeskim. Studia i prace wydziału nauk ekonomicznych i zarządzania nr 40, t. 1. Szczecin: Wydawnictwo Naukowe Uniwersytetu Szczecińskiego.

2. Dömötör, R. (red.) (2013). Twin Entrepreneurs Vienna - Bratislava. Regional Study. Wiedeń i Bratysława: Vienna Business Agency i Young Entrepreneurs Association Slovakia Pobrane z: http://www.twinentrepreneurs.eu/media/file/8_TwinEntrepreneurs_Regional_Study.pdf.

3. Ivaničková, A., Vlčková, V. (2005). Chápanie cezhraničnej spolupráce v navrhovanej regionálnej politike Európskej únie na programovacie obdobie 2007-2013. Medzinárodné vzt'ahy, 3(2), 10.

4. Lechwar, M. (2012). Instytucjonalny wymiar współpracy transgranicznej w regionie podkarpackim. Nierówności Społeczne a Wzrost Gospodarczy, 26, 168-179.

5. Mattoš, B. (2014). Determinanty współpracy transgranicznej Austrii i Republiki Słowackiej. Rola Bratysławy i Wiednia w rozwoju wzajemnych kontaktów. Pogranicze. Polish Borderlands Studies, 2(2), 184195.

6. Modzelewski, W.T. (2015). Kontakty zagraniczne samorządu województwa warmińsko-mazurskiego. W: W.T. Modzelewski (red.), Region Warmii i Mazur w europejskich procesach integracyjnych (s. 85-101). Olsztyn: INP UWM.

7. Št’astný, Z. (2003) Sociologické výskumy slovensko-rakúskeho pohraničia. W: L. Falt’an (red.), Mentálna hranica. Obraz suseda v slovensko-rakúskom pohraničí (s. 23-37). Bratysława: Sociologický ústav SAV.

8. Szul, R. (2001). Uwarunkowania lokalnej współpracy transgranicznej. Polski Przegląd Dyplomatyczny, 1(2), 89-98.

9. Zabielska, I. (2013). Transgraniczna współpraca regionów. W: R. Kisiel, M. Wojarska (red.), Wybrane aspekty rozwoju regionalnego (s. 46-74). Olsztyn: Fundacja „Wspieranie i Promocja Przedsiębiorczości na Warmii i Mazurach".

10. http://www.euroregionbeskidy.pl/pl/index.php?option=com_content\&view=article\&id=62\&Itemid $=60$

11. Europejska Karta Regionów granicznych i transgranicznych. Pobrane z: http://archiwum-ukie.polskawue.gov.pl/HLP/files.nsf/0/5E37B3BC73FF3C33C1256E86004711F1/\$file/karta.pdf

12. Europejska polityka sąsiedztwa. http://www.europarl.europa.eu/atyourservice/pl/displayFtu.html?ftuId=FTU_6.5.4.html

13. Priorytety polskiej polityki zagranicznej 2012-2016. Pobrane z: http://www.msz.gov.pl/resource/ aa1c4aec-a52f-45a7-96e5-06658e73bb4e:JCR 
14. Traktat o funkcjonowaniu Unii Europejskiej. Pobrane z: http://oide.sejm.gov.pl/oide/index.php?option=com_content\&view=article\&id=14804\&Itemid=946

15. Traktat o Unii Europejskiej. Pobrane z: http://oide.sejm.gov.pl/oide/index.php?option=com_content\&view=article \&id=14803\&Itemid=945

16. Europejska Karta Samorządu Terytorialnego, sporządzona w Strasburgu dnia 15 października 1985 r. Dz.U. 1994 nr 124 poz. 607. Pobrane z: http://isap.sejm.gov.pl/DetailsServlet?id=WDU19941240607

17. Konstytucja Rzeczypospolitej Polskiej z dnia 2 kwietnia 1997 Dz.U. 1997 nr 78 poz. 483. Pobrane z: http://isap.sejm.gov.pl/DetailsServlet?id=WDU19970780483

18. Ustawa z dnia 15 września 2000 r. o zasadach przystępowania jednostek samorządu terytorialnego do międzynarodowych zrzeszeń społeczności lokalnych i regionalnych Dz.U. 2000 nr 91 poz. 1009. Pobrane z: http://isap.sejm.gov.pl/DetailsServlet?id=WDU20000911009

19. Wybrane projekty realizowane w ramach Programu Operacyjnego Współpracy Transgranicznej Polska (Województwo Lubuskie) - Brandenburgia 2007 - 2013. Pobrane z: https://www.ewt.gov.pl/media/858/PLBB_.pdf

20. http://www.umwd.dolnyslask.pl/ewt/projekty-wlasne-urzedu/strategia-zintegrowanej-wspolpracy-czesko-polskiego-pogranicza/aktualnosci/artykul/polsko-czeskie-euwt-zmienilo-nazwe-1/

21. http://wroclaw.stat.gov.pl/cps/rde/xbcr/wroc/ASSETS_14-19.pdf

22. http://www.pbu2020.eu/pl/ 